\title{
Kajian Analisa: Penerapan dan Pengembangan e-Government pada Pemerintah Propinsi Bali
}

\author{
Analytical Review: Implementation and Development of e-Government Bali
}

\author{
Ni Ke tut Dewi Ari Jayanti*1 \\ ${ }^{1}$ Program Studi Sistem Informasi, STMIK STIKOM Bali \\ E-mail: *1daj@stikom-bali.ac.id
}

\begin{abstract}
Abstrak
eGovernment merupakan salah satu upaya untuk mengembangkan penyelenggaraan kegiatan kepemerintahan yang berbasis elektronik dalam rangka meningkatkan kualitas layanan kepada berbagai pihak secara efektif dan efisien. Pihak pengguna eGovernment mencakup populasi yang luas, baik kalangan pemerintah, warga negara maupun kalangan bisnis, sehingga pada akhirnya tercipta hubungan yang saling menguntungkan. Penerapan eGovernment di Bali pada umumnya baru pada tahap yang sangat awal, yaitu tahap publish. Bahkan informasi yang dipublish tersebut sudah kadaluarsa, karena tidak pernah diupdate. Disamping itu belum adanya kajian analisa penerapan eGovernment yang dapat dijadikan acuan dalam pengembangan eGovernment, serta tingkat keberhasilan penerapannya. Metode penelitian ini diawali dengan pengambilan data yang dilanjutkan dengan mengidentifikasikan permasalahan dengan menggunakan teknik PIECES (Performance, Information, Economics, Control and Security, Efficiency, Service). Tahap berikutnya, menganalisa permasalahan yaitu dengan mengidentifikasikan permasalahan dan sebab akibatnya untuk memperoleh System Improvement Objective. Tahapan ini dilakukan dengan mengadopsi tahap Problem Analysis dari metodologi FAST (Framework forThe Application of System Techniques). Penelitian dilakukan pada pemerintahan Propinsi Balidan penelitian ini menghasilkan kajiananalisapenerapaneGovernmentyang dapat dijadikan acuan dalam pengembangan proyek eGovernment, khususnya di wilayah Bali.
\end{abstract}

Kata Kunci - eGovernment, PIECES, FAST, Pemerintah Propinsi Bali

\begin{abstract}
eGovernment is one of the efforts to develop the implementation of electronic-based governance activities in order to improve the quality of service to various parties effectively and efficiently. The users of eGovernment cover a vast population, both government, citizens and business, so that in the end create a mutually beneficial relationship. The implementation of eGovernment in Bali is generally only at a very early stage, namely the publish stage. Even the published information has expired, because it was never updated. Besides, there is no analysis of the implementation of eGovernment that can be used as a reference, as well as the success rate of its application. This research method begins with data retrieval followed by identifying problems using PIECES technique (Performance, Information, Economics, Control and Security, Efficiency, Service). The next stage, analyze the problem is to identify the problems and causation to obtain System Improvement Objective. This stage is done by adopting the Problem Analysis stage of the FAST methodology (Framework for The Application of System Techniques). This research was conducted at the provincial government of Bali and this study resulted analytical review implementation of eGovernment which can be used as a reference in the development of eGovernment projects, especially in the area of Bali.
\end{abstract}

Keywords - eGovernment, PIECES, FAST, Bali Provincial Government 


\section{PENDAHULUAN}

Berkembangnya teknologi internet sebagai tulang punggung teknologi komunikasi data di antara pengguna komputer baik untuk tingkat korporasi maupun personal, telah mendorong sebagian besar negara di dunia untuk mengimplementasikan teknologi internet guna meningkatkan pelayanan kepada masyarakatnya dalam bentuk sistem informasi nasional (Sisfonas). Perkembangan ini juga telah mendorong pihak pemerintah untuk mendayagunakan seluruh sumberdaya yang ada untuk meningkatkan pelayanan kepada masyarakat. Upaya tersebut dikenal dengan istilah eGovernment. eGovernment dapat didefinisikan secara umum sebagai "Pemanfaatan teknologi informasi seperti internet, telepon, satelit oleh institusi pemerintahan untuk meningkatkan kinerja pemerintah dalam hubungannya dengan masyarakat, komunitas bisnis dan kelompok lainnya" [1]. Secara khusus eGovernment adalah suatu aplikasi sistem informasi yang digunakan dalam berbagai kegiatan pemerintahan. eGovernment memiliki konteks hubungan yang luas yang terdiri dari hubungan antara pemerintah dengan masyarakat (G2C), pemerintah dengan dunia bisnis (G2B) dan instansi pemerintah dengan instansi pemerintah lainnya (G2G).

Pada penelitian sebelumnya yang dilakukan oleh Loura H., pada penelitiannya yang berjudul Studi Penerapan eGovernment di Indonesia dan Negara lainnya sebagai Solusi Pemberantasan Korupsi di Sektor Publik mengemukakan bahwa banyak negara termasuk Indonesia menerapkan eGovernment dalam berbagai bentuk untuk meningkatkan prinsip-prinsip good governance dalam rangka memberantas krupsi, diantaranya pengadaan barang dan jasa, perpajakan, dan juga perijinan. Meskipun demikian, masih banyak hal yang perlu diperbaiki oleh Indonesia dalam menerapkan eGovernment, antara lain percepatan pembuatan peraturan perundang-undangan dan kebijakan untuk mendukung eGovernment di daerah; pengadaan sarana prasarana pengembangan infrastruktur untuk menciptakan akses komunikasi handal; pemberdayaan sumber daya manusia; pengembangan perangkat lunak yang diperlukan; serta pengembangan organisasi dan tata kerja yang medukung eGovernment [2].

Penelitian lainnya dilakukan oleh Diah R. A., pada penelitiannya yang berjudul Penerapan Kebijakan eGovernment dalam Peningkatan Mutu Pelayanan Publik di Kantor Kecamatan Sambutan Kota Samarinda mengemukakan bahwa penerapan kebijakan eGovernment dalam peningkatan mutu pelayanan publik di kantor kecamatan Sambutan kota Samarinda merupakan tindakan pemerintah dalam pelaksanaan suatu peraturan dalam hal pemberian suatu pelayanan publik melalui penggunaan media teknologi informasi secara elektronis untuk pemenuhan kebutuhan masyarakat yang sesuai dengan hak-hak dasar setiap warganegara. Hasil pada penelitian ini ditemukan bahwa penerapan kebijakan eGovernment dalam peningkatan mutu pelayanan publik di kantor kecamatan Sambutan kota Samarinda mulai mengalami perubahan pada pelayanan prima walaupun masih ada terdapat beberapa kekurangan yakni terbatasnya sumber daya yang dimiliki, kurangnya sosialisasi kebijakan kepada masyarakat, dan miskomunikasi antara pimpinan dan pegawai [3].

Penelitian lainnya dilakukan oleh Dien N., pada penelitiannya yang berjudul FaktorFaktor Penghambat Pengembangan eGovernment: Studi Kasus Pemerintah Kota Palembang Sumatera Selatan mengemukakan bahwa kendala utama di Indonesia dalam menerapkan eGovernment adalah faktor SDM, infrastruktur, dan organisasi. Hasil penelitian yang diperoleh menyatakan bahwa kendala sumber daya manusia, kendala infrastruktur dan kendala organisasi berpengaruh dalam memprediksi hambatan pengembangan e-government [4].

Penelitian lainnya yang dilakukan oleh Jayanti, pada penelitiannya yang berjudul State of the Art: Riset Pengembangan eGovernment dinyatakan bahwa penerapan pengembangan eGovernment dimaksudkan bukan saja untuk memperlancar komunikasi, pertukaran informasi dan pelaksanaan koordinasi antar instansi pemerintah (G2G), tetapi juga meningkatkan kerjasama dan pelayanan kepada sektor swasta (G2B) dan meningkatkan kualitas pelayanan kepada masyarakat (G2C), sehingga tercipta tata pemerintahan yang baik, efektif, dan efisien [5].

Penelitian lainnya yang dilakukan oleh Riyadi S., dkk., pada penelitiannya yang berjudul Pemodelan Enterprise Architecture Pelayanan di RSUD Murjani Sampit mengemukakan bahwa 
proses pengembangan aplikasi yang belum tertata dan terdokumentasi dengan baik dan hanya memperhatikan kebutuhan sesaat memungkinkan penerapan sistem informasi yang saling tumpang tindih. Hal tersebut membuat sistem informasi tidak dapat dimanfaatkan sesuai yang diharapkan yaitu efesiensi dan efektifitas. Hasil yang diperoleh dari penelitian ini adalah blueprint enterprise architecture pelayanan RSUD Murjani, yang menggambarkan elemen-elemen arsitektur organisasi yang saling berkaitan antar elemen-elemen tersebut, sehingga menjadi salah satu sumber pengambilan keputusan organisasi yang terus mengalami perubahan [6].

Di wilayah Propinsi Bali, penerapan eGovernment ini menjadi populer sehubungan dengan diberlakukannya otonomi daerah. Implementasi eGovernment dengan bantuan teknologi informasi dan komunikasi membuka peluang baru untuk lebih mengeksplorasi informasi sehingga dapat dimanfaatkan secara maksimal. Pengguna eGovernment mencakup populasi yang luas, baik untuk kalangan pemerintah, warga negara maupun kalangan bisnis, sehingga pada akhirnya tercipta hubungan yang saling menguntungkan. Walaupun demikian, pengembangan eGovernment di wilayah Propinsi Bali belum maksimal, karena sebagian besar hanya menyediakan berita-berita umum pada situs-situs instansi pemerintah daerah. Penerapan eGovernment di wilayah Bali pada umumnya baru pada taraf yang sangat awal, yaitu taraf publish. Bahkan tidak jarang informasi yang di publish tersebut sudah kadaluarsa, karena tidak pernah di update.

Berdasarkan hal tersebut diatas, perlu dilakukan kajian analisa penerapan eGovernment yang dapat dijadikan acuan dalam pengembangan eGovernment di wilayah Propinsi Bali.

\section{METODE PENELITIAN}

Penelitian yang akan dilakukan menggunakan pendekatan dari metodologi menurut Yin pada Hafedh yang menyatakan rancangan penelitian merupakan urutan logika yang menghubungkan data empiris terhadap suatu kajian, yang diawali dengan research question dan pada akhirnya memperoleh suatu kesimpulan dan menurut Bouma pada Hafedh yang merekomendasikan pemilihan suatu metode dan rancangan penelitian bertujuan untuk menjawab pertanyaan penelitian dan memenuhi tujuan penelitian [7].

Metodologi penelitian ini diawali dengan pengambilan data dan mengidentifikasikan permasalahan yang akan dibahas pada penelitian ini. Tahap berikutnya, menganalisa permasalahan untuk memperoleh System Improvement Objective. Tahapan metodologi diuraikan sebagai berikut:

1. Pengambilan Data

Untuk dapat mengetahui kendala yang dihadapi dalam menerapkan eGoverment dan untuk mengetahui faktor-faktor yang menjadi pengaruh dalam mengembangkan eGovernment, dilakukan proses pengambilan data dari beberapa unit pelayanan terpadu di pemerintah provinsi Bali.

2. Indentifikasi Masalah

Pada tahap identifikasi masalah, peneliti mengklasifikasi permasalahan penerapan dan pengembangan eGovernment kedalam daftar klasifikasi permasalahan eGovernment. Dari daftar klasifikasi permasalahan eGovernment tersebut, menghasilkan daftar problems, opportunities, dan directives. Semua problems, opportunities dan directives dari sistem manual yang ada digali dengan menggunakan kerangka PIECES (Performance, Information, Economics, Control and Security, Efficiency, Service).

3. Kajian Analisis

Pada tahap ini dilakukan analisa permasalahan, yaitu dengan mengidentifikasikan permasalahan dan sebab akibatnya. Hasil dari tahapan sebelumnya, digunakan sebagai input dalam tahap ini dengan menekankan sebab akibat dari problems, opportunities dan directives. Setelah dilakukan analisa permasalahan dan sebab akibat, diperoleh hasil analisa permasalahan ini yaitu sasaran perbaikan sistem (system improvement objectives). Tahapan ini dilakukan dengan mengadopsi tahap Problem Analysis dari metodologi FAST. 
Berdasarkan system improvement objectives dan analisa permasalahan, maka sistem baru yang akan dibangun harus memiliki kemampuan-kemampuan yang dibutuhkan. Untuk itu, selanjutnya dilakukan analisa kebutuhan dengan mengadopsi tahap requirement analysis dari metodologi FAST. Hasil dari tahap analisa kebutuhan ini adalah daftar analisa kebutuhan. Setelah menetapkan kebutuhan yang harus dimiliki oleh sistem yang akan dibangun, selanjutnya dilakukan analisa keputusan yang dapat digunakan dalam mengembangkan eGovernment. Tujuan dari analisa keputusan ini adalah menemukan solusi terbaik berdasarkan pertimbangan-pertimbangan yang dimiliki. Sama halnya dengan analisa permasalahan dan analisa kebutuhan, analisa keputusan ini juga diadopsi dari tahap decision analysis pada metodologi FAST.

\section{HASIL DAN PEMBAHASAN}

Hal-hal yang dirasa perlu untuk dipahami adalah harus diketahui dengan jelas alasan mengapa eGovernment harus diterapkan sehingga perlu didefinisikan secara jelas visi dari penerapan dan pengembangan eGovernment tersebut. Pada pembahasan berikut dijabarkan mengenai pengambilan data serta identifikasi terhadap masalah-masalah yang ada dalam penerapan eGovernment

\subsection{Pengambilan Data}

Mengembangkan eGovernment merupakan sesuatu yang kompleks dan sulit untuk dilakukan. Meskipun pada kenyataannya sistem Information and Communication Technology (ICT) pada suatu daerah sudah baik namun mereka juga masih khawatir dengan masalah teknologi dan budaya. Hal-hal yang dirasa perlu untuk dipahami adalah harus diketahui dengan jelas alasan mengapa eGovernment harus diterapkan sehingga perlu didefinisikan secara jelas visi dari penerapan dan pengembangan eGovernment tersebut. Yang tidak kalah pentingnya adalah harus diketahui faktor-faktor yang mempengaruhi pengembangan eGovernment, tahapan-tahapan eGovernment yang perlu diimplementasikan serta model eGovernment yang optimal yang dapat diterapkan pemerintah propinsi Bali.

Pengambilan data diperoleh dengan melakukan pengamatan langsung terhadap situs pemerintah propinsi Bali pada tautan http://www.baliprov.go.id/v1/ . Pada situs pemerintah propinsi Bali terdapat 7 istem informasi eGovernment yaitu (1) Simantri, (2) Bedah Rumah, (3) E-JKBM, (4) LPSE, (5) ATCS, (6) PPID dan (7) Transparansi Anggaran (tampilan pada gambar 1). Dari 7 sistem informasi tersebut terdapat 3 tautan yang belum dapat diakses karena masih ditangguhkan. Berdasarkan pengamatan langsung yang dilakukan, dari 4 tautan lainnya diperoleh data awal berupa kendala-kendala yang dihadapi dalam menerapkan sistem eGovernment pada pemerintah provinsi Bali terdiri dari kendala infrastruktur, budaya, politik, dukungan dari pemegang kekuasaan, undang-undang dan keamanan dan harapan serta kebutuhan pengguna.

Saat ini di Indonesia, kebijakan pemerintah yang dituangkan dalam bentuk Inpres dan Keputusan Menteri Komunikasi dan Informasi tentang pengembangan eGovernment merupakan wujud keinginan pemerintah dalam upaya mendorong bangsa Indonesia menuju masyarakat informasi. 


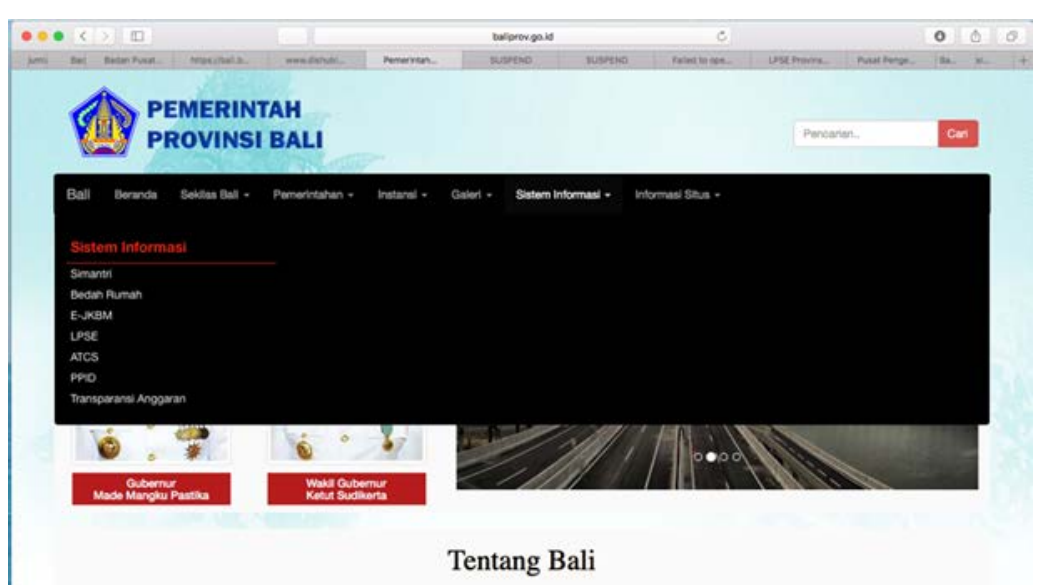

Gambar 1. Situs Pemerintah Propinsi Bali

\subsection{Identifikasi Masalah}

Pengalaman daerah negara-negara lain, seperti yang telah dipaparkan penelitian sebelumnya, dijadikan sebagai pembelajaran dalam mengklasifikasikan permasalahanpermasalahan dalam penerapan eGovernment. Pada pemerintah provinsi Bali sendiri penerapan eGovernment dilakukan dengan memanfaatkan website sebagai media komunikasi dengan masyarakat. Berdasarkan kerangka PIECES (Performance, Information and Data, Economics, Control and Security, Efficiency, Service), permasalahan yang ada saat ini dapat dinarasikan sebagai berikut:

1. Performance

Dalam proses pelaksanaan proyek eGovernment, tidak semua berhasil dilaksanakan. Hal ini disebabkan karena kurangnya dukungan dari pemegang kekuasaan dalam pengembangan eGovernment. Beberapa negara yang telah berhasil dalam mengembangkan dan menerapkan eGovernment adalah Kolombia, Kenya, India, Malaysia, Amerika, Palestina, Korea Selatan. Sedangkan negara yang tidak berhasil dalam mengembangkan dan menerapkaneGovernment adalah Mozambique dan Uganda. Performance diukur berdasarkan manfaat yang telah dirasakan masyarakat dan pemerintah dalam menerapkan eGovernment.

2. Information

Pengamatan yang dilakukan terhadap situs-situs eGovernment dan pengalaman-pengalaman beberapa negara dalam mengembangkan dan menerapkan yang ada saat ini menampilkan informasi yang tidak relevan, karena tidak di-update secara berkala.

3. Economics

Karena belum adanya tahapan-tahapan yang dijadikan acuan dalam pengembangan eGovernment, sehingga penerapan eGovernment masih belum berhasil dilaksanakan. Sebagai contoh, misalnya tahap awal proyek pengembangan sistem adalah perencanaan. Pada tahap awal ini ditentukan ruang lingkup proyek, kebutuhan dan batasan, partisipan proyek, biaya, jadwal. Hal ini perlu ditentukan untuk menilai kelayakan dari suatu proyek pengembangan eGovernment.

4. Control and Security

a. Tidak adanya kontrol dan monitoring dalam penerapan eGovernment.

b. Kurangnya kesediaan dan kemampuan masyarakat dalam penggunaan ICT

c. Keamanan data dan jaringan masih belum memadai.

5. Efficiency

Hingga saat ini, pemerintah mengalami kesulitan dalam meng-update informasi pada situsnya. Hal ini dikarenakan belum maksimalnya sarana yang memudahkan proses tersebut.

6. Services

Pelayanan pemerintah terhadap masyarakat hingga saat ini belum optimal. Kurangnya sosialisasi dan program-program insentif pemerintah dalam bidang eGovernment. 
Masalah - masalah yang telah dikemukakan diatas dirangkum dalam suatu daftar permasalahan. Permasalahan tersebut diklasifikasi ke dalam empat kelas yaitu: regulasi, SDM / user, infrastruktur, dan aplikasi. Hasil klasifikasi tersebut dirangkum dalam daftar klasifikasi permasalahan e-government pada Tabel 1.

Tabel 1. Daftar Klasifikasi Permasalahan Penerapan eGovernment

\begin{tabular}{|c|l|c|}
\hline NO & \multicolumn{1}{|c|}{ PERMASALAHAN } & \multicolumn{1}{|c|}{ KLASIFIKASI } \\
\hline 1. & $\begin{array}{l}\text { Kurangnya dukungan (visi, constitution, anggaran biaya) dari pemegang } \\
\text { kekuasaan dalam penerapan dan pengembangan proyek eGovernment. }\end{array}$ & Regulasi \\
\hline 2. & $\begin{array}{l}\text { Belum adanya tahapan-tahapan yang dijadikan acuan dalam pengembangan } \\
\text { eGovernment } t .\end{array}$ & Regulasi \\
\hline 3. & $\begin{array}{l}\text { Belum adanya sebuah badan atau organisasi yang independent yang dapat } \\
\text { mengatur dan memonitor penerapan eGovernment. }\end{array}$ & Regulasi \\
\hline 4. & $\begin{array}{l}\text { Masih kurangnya kesediaan masyarakat serta minimnya kemampuan } \\
\text { masyarakat khususnya dipedesaan dalam penggunaan ICT. }\end{array}$ & SDM \\
\hline 5. & Infrastruktur yang ada belum memadai. & Infrastruktur \\
\hline 6. & $\begin{array}{l}\text { Belum maksimalnya sarana yang memudahkan pemerintah meng-update } \\
\text { informasi pada situsnya. }\end{array}$ \\
\hline
\end{tabular}

Dari daftar klasifikasi permasalahan pada Tabel 1, menghasilkan daftar problems, opportunities, dan directives. Daftar tersebut dirangkum pada Tabel 2.

Tabel 2. Daftar Problems, Opportunities, dan Directives

\begin{tabular}{|l|l|}
\hline I. & Problems \\
\hline 1. & Belum adanya acuan dalam penerapan dan pengembangan eGovernment. \\
\hline 2. & Belum jelasnya tahapan yang harus dilakukan dalam melaksanakan proyek eGovernment \\
\hline II. & Opportunities \\
\hline 1. & Sistem dapat menyediakan acuan tahapan serta informasi untuk instansipemerintah \\
\hline 2. & Sistem menyediakan sarana bagi terciptanya informasi yang update dan relevan. \\
\hline 3. & $\begin{array}{l}\text { Sistem mampu menyediakan pelayanan masyarakat yang tidak terbatas pada waktu, ruang, } \\
\text { sehingga mampu meningkatakan pelayanan terhadap masyarakat. }\end{array}$ \\
\hline III. & Directives \\
\hline 1. & Sistem tidak mengubah struktur organisasi pemerintah yang sudah ada. \\
\hline 2. & Sistem dapat mempermudah prosedur pelaksanaan proyek eGovernment. \\
\hline 3. & Sistem yang dibangun, disesuaikan dengan kondisi infrastruktur daerah. \\
\hline
\end{tabular}

\subsection{Kajian Analisa}

Dalam pembahasan ini akan dilakukan analisa yaitu dengan mengidentifikasi permasalahan dan sebab-akibatnya. Hasil dari tahapan sebelumnya, digunakan sebagai input dalam tahap ini dengan menekankan sebab akibat dari problems, opportunities dan directives. Hasil analisa permasalahan ini adalah sasaran perbaikan sistem (System Improvement Objectives). Tahapan dari metodologi FAST yang diadopsi terdiri atas:

1. Problem Analysis, yaitu mengidentifikasikan permasalahan dan sebab akibatnya. Hasil dari tahapan ini adalah analisa sebab akibat dan system improvement objectives.

2. Requirement Analysis, berdasarkan system improvement objectives dan analisa permasalahan, maka sistem baru yang akan dibangun harus memiliki kemampuankemampuan yang dibutuhkan. Hasil dari tahapan ini adalah daftar analisa kebutuhan.

3. Decision Analysis, setelah menetapkan kebutuhan yang harus dimiliki oleh sistem yang akan dibangun, selanjutnya dilakukan analisa keputusan yang dapat digunakan dalam mengembangkan e-Government. Tujuan dari analisa keputusan ini adalah menemukan solusi terbaik berdasarkan pertimbangan-pertimbangan yang dimiliki. Hasil dari tahapan ini adalah daftar analisa keputusan. 


\subsubsection{Problem Analysis (Analisa Masalah)}

Pada pembahasan ini, diberikan analisa permasalahan terhadap problems, opportunities, dan directives dengan mengidentifikasikan permasalahan dan sebab akibatnya. Selanjutnya akan diberikan kriteria-kriteria yang dibutuhkan serta batasan-batasan yang ada. Setelah melihat problems, opportunities, dan directives yang telah dibahas sebelumnya, dapat diberikan analisa sebab akibat dari permasalahan yang telah diidentifikasi. Hasil analisa sebabakibat permasalahan, dirangkum pada tabel berikut ini:

Tabel 3. Analisa Sebab Akibat

\begin{tabular}{|c|c|c|}
\hline \multicolumn{3}{|c|}{ I. $\quad$ Problems } \\
\hline 1. & $\begin{array}{l}\text { Belum adanya acuan dalam penerapan dan } \\
\text { pengembangan } e \text { Government. }\end{array}$ & $\begin{array}{l}\text { Sebab: } \\
\text { 1. Kurangnya pemahaman mengenai manfaat } \\
\text { penerapan eGovernment. } \\
\text { 2. Belum ada visi penerapan dan pengembangan } \\
\text { eGovernment yang jelas dari pemerintah. } \\
\text { Akibat: } \\
\text { Akibatnya penerapan dan pengembangan } \\
\text { eGovernment dirasa tidak terlalu dibutuhkan. }\end{array}$ \\
\hline 2. & $\begin{array}{l}\text { Belum jelasnya tahapan yang harus } \\
\text { dilakukan dalam melaksanakan proyek } \\
\text { eGovernment }\end{array}$ & $\begin{array}{l}\text { Sebab: } \\
\text { Selama ini belum ada tahapan-tahapan dalam } \\
\text { melaksanakan proyek eGovernment. } \\
\text { Akibat: } \\
\text { Diharapkan pada akhirnya mampu membantu } \\
\text { seluruh kantor pemerintah dalam melaksanakan } \\
\text { proyek eGovernment. }\end{array}$ \\
\hline \multicolumn{3}{|c|}{ II. Opportunities } \\
\hline 1. & $\begin{array}{l}\text { Adanya peluang untuk menyediakan } \\
\text { standardisasidalam penerapan dan } \\
\text { pengembangan eGovernment. }\end{array}$ & $\begin{array}{l}\text { Sebab: } \\
\text { Berdasarkan studi literatur yang dilakukan, belum } \\
\text { adanya standardisasi karena belum ada prosedur } \\
\text { yang mengatur hal tersebut. } \\
\text { Akibat: } \\
\text { Dengan adanya standardisasiters ebut diharapkan } \\
\text { pemerintah lebih memiliki kesiapan dalam } \\
\text { menerapkan eGovernment. }\end{array}$ \\
\hline 2. & $\begin{array}{l}\text { Adanya peluang untuk membangun sebuh } \\
\text { sistem pengembangan eGovernment. }\end{array}$ & $\begin{array}{l}\text { Sebab: } \\
\text { Sistem pengembangan yang ada masih belum } \\
\text { memadai karena belum menggambarkan secara } \\
\text { jelas tahapan-tahapan yang perlu dilaksanakan, } \\
\text { faktor-faktor kritis yang menjadi kendala serta } \\
\text { deliverables yang dihasilkan. } \\
\text { Akibat : } \\
\text { Dengan sistem pengembangan yang memadai } \\
\text { diharapkan dapat membantu dalam melaksanakan } \\
\text { proyek eGovernment. }\end{array}$ \\
\hline
\end{tabular}

Berdasarkan analisa sebab akibat tersebut, yang menjadi sasaran dalam penerapan dan pengembangan eGovernment adalah untuk menyediakan sebuah sistem pengembangan yang optimal di pemerintah provinsi Bali, sehingga pelayanan pemerintah terhadap masyarakat dapat ditingkatkan. Sedangkan sasaran khusus penerapan dan pengembangan eGovernment ini adalah:

1. Pengembangan suatu model yang dapat dijadikan acuan dalam penerapan dan pengembangan eGovernment.

2. Pengembangan sebuah sistem yang memadai yang dapat menggambarkan secara jelas tahapan-tahapan yang perlu dilaksanakan, faktor-faktor kritis yang menjadi kendala serta keluaran yang dihasilkan. 
Berdasarkan sasaran tersebut diatas maka ada beberapa hal yang menjadi tujuan dalam penelitian ini. Berikut merupakan tujuan (objectives) penelitan dan batasan-batasannya (constraint) yang dirangkum dalam Tabel 4 tentang System Improvement Objectives.

Tabel 4. System Improvement Objectives

\begin{tabular}{|c|c|c|}
\hline \multicolumn{2}{|r|}{ System Objectives } & System Constraint \\
\hline 1. & $\begin{array}{l}\text { Membuat suatu model eGovernment yang } \\
\text { optimal bagi pemerintah propinsi Bali }\end{array}$ & $\begin{array}{l}\text { 1. Komponen - komponen yang disajikan } \\
\text { pada model eGovernment terbatas pada } \\
\text { studi literatur dari pengamatan terhadap } \\
\text { beberapa daerah dan negara yang telah } \\
\text { menerapkan eGovernment. }\end{array}$ \\
\hline 2. & $\begin{array}{l}\text { Membuat sebuah siklus pengembangan } \\
\text { eGovernment yang dapat dijadikan } \\
\text { pedoman dalam melaksanakan proyek } \\
\text { eGovernment }\end{array}$ & $\begin{array}{l}\text { 1. Tahapan - tahapan yang disajikan terbatas } \\
\text { pada dasar acuan metodologi yang } \\
\text { digunakan. }\end{array}$ \\
\hline
\end{tabular}

\subsubsection{Requirement Analysis (Analisa Kebutuhan)}

Berdasarkan system improvement objectives dan analisa permasalahan, maka sistem baru yang akan dibangun harus memiliki kemampuan-kemampuan yang dibutuhkan. Berikut merupakan analisa kebutuhan yang dirangkum dalam Tabel 5.

Tabel 5. Analisa Kebutuhan

\begin{tabular}{|l|l|}
\hline Kebutuhan Fungsional & $\begin{array}{l}\text { 1. Model harus bisa dijadikan acuan dalam penerapan dan } \\
\text { pengembangan eGovernment. }\end{array}$ \\
& $\begin{array}{r}\text { 2. } \begin{array}{l}\text { Sistem pengembangan eGovernment dapat menggambarkan secara } \\
\text { jelas tahapan-tahapan yang perlu dilaksanakan, faktor-faktor kritis } \\
\text { yang menjadi kendala serta keluaran yang dihasilkan. }\end{array} \\
\hline \text { Kebutuhan Non Fungsional }\end{array}$ \\
$\begin{array}{l}\text { 1. Sistem yang dibangun dapat disesuaikan dengan tingkat computer } \\
\text { literacy di Bali. } \\
\text { 2. Sistem mudah digunakan oleh masyarakat. }\end{array}$ \\
\hline
\end{tabular}

\subsubsection{Decision Analysis (Analisa Keputusan)}

Setelah menetapkan kebutuhan yang harus dimiliki oleh sistem yang akan dibangun, ada beberapa solusi yang dapat digunakan dalam membangun eGovernment. Pada pembahasan ini akan diberikan subsystems yang dijadikan acuan dalam membangun eGovernment sebagai solusi atas masalah dan kebutuhan yang sudah didefinisikan pada pembahasan sebelumnya. Tujuan dari pembahasan ini adalah menemukan solusi terbaik berdasarkan pertimbangan-pertimbangan yang dimiliki.

Adapun subsystems yang dapat dijadikan acuan dalam membangun eGovernment adalah sebagai berikut:

1. Sistem eGovernment, merupakan aplikasi-aplikasi elektronik pada pemerintah.

2. Leadership, merupakan dukungan dari pemegang kekuasaan (pemerintah).

3. Entitas eGovernment, merupakan organisasi yang mengatur penerapan dan pengembangan e-government.

4. Pengguna, dalam hal ini bisa masyarakat dan pemerintah.

Infrastruktur, merupakan teknik arsitektur yang menghubungkan dan mengintegrasikan tingkat pemerintahan dan SKPD. 


\section{KESIMPULAN}

Dari hasil pengamatan, pengidentifikasian masalah serta analisa, diperoleh kesimpulan penelitian yaitu:

1. Hal-hal yang menjadi kendala atau permasalahan dalam penerapan dan pengembangan eGovernment adalah:

a. Kurangnya dukungan (visi, constitution, anggaran biaya) dari pemegang kekuasaan dalam penerapan dan pengembangan eGovernment.

b. Belum adanya tahapan-tahapan yang dijadikan acuan dalam pengembangan eGovernment.

c. Belum adanya sebuah badan atau organisasi yang independent yang dapat mengatur dan memonitor penerapan dan pengembangan eGovernment.

d. Masih kurangnya kesediaan masyarakat serta minimnya kemampuan masyarakat dalam penggunaan ICT.

e. Infrastruktur yang ada belum memadai.

f. Belum adanya sarana yang memudahkan pemerintah meng-update informasi pada situsnya

2. Penyusunan rumusan pengembangan eGovernment yang optimal pada pemerintah provinsi Bali disusun berdasarkan analisa sebab akibat, analisa kebutuhan serta analisa keputusan yang dilakukan. Dalam penyusunan rumusan pengembangan eGovernment ini melibatkan subsystems, yaitu:

a. Sistem eGovernment, merupakan aplikasi-aplikasi elektronik pada pemerintah.

b. Leadership, merupakan dukungan dari pemegang kekuasaan (pemerintah).

c. Entitas eGovernment, merupakan organisasi yang mengatur penerapan dan pengembangan eGovernment.

d. User, dalam hal ini bisa masyarakat dan pemerintah.

e. Infrastruktur, merupakan teknik arsitektur yang menghubungkan dan mengintegrasikan tingkat pemerintahan dan SKPD.

\section{SARAN}

Untuk pengembangan penelitian lebih lanjut, terdapat beberapa hal yang dapat dikembangkan, yaitu:

1. Merumuskan model eGovernment yang bertujuan untuk membantu pemerintah provinsi Bali dalam merencanakan dan mengimplementasikan eGovernment yang lebih baik

2. Merumuskan siklus pengembangan eGovernment, yang terkait dengan aplikasi eGovernment yaitu G2C, G2B dan G2G.

\section{Ucapan Terima Kasih}

Penulis mengucapkan terima kasih kepada STMIK STIKOM Bali yang telah memberikan dukungan finansial terhadap penelitian ini serta ucapan terima kasih kepada rekan-rekan yang telah mendukung penulis dalam menyelesaikan penelitian ini. 


\section{DAFTAR PUSTAKA}

[1] The World Bank Group, 2007, eGovernment Definition.

http://www1.worldbank.org/publicsector/egov/definition.htm, Diakses pada tanggal 11 Juli 2017.

[2] Loura H., 2014, Studi Penerapan eGovernment di Indonesia dan Negara lainnya sebagai Solusi Pemberantasan Korupsi di Sektor Publik, Jurnal Rechts Vinding, Vol. 3, No. 3.

[3] Diah R.A., 2016. Penerapan Kebijakan eGovernment dalam Peningkatan Mutu Pelayanan Publik di Kantor Kecamatan Sambutan Kota Samarinda, eJournal Ilmu Pemerintahan. Vol. 4, No.4

[4] Dien N., 2014. Faktor-Faktor Penghambat Pengembangan eGovernment: Studi Kasus Pemerintah Kota Palembang, Sumatera Selatan, Jurnal Eksplora Informatika. Vol. 4, No. 1.

[5] Jayanti N.K.D.A, 2009, State of the Art: Riset Pengembangan eGovernment, Prosiding Seminar Nasional Teknologi Informasi, Vol 6, No 1.

[6] Riyadi S., Soedijono B., Amborowati A., 2015, Pemodelan Enterprise Architecture Pelayanan di RSUD Murjani Sampit, Jurnal CITEC. Vol. 2, No. 4.

[7] Alshihi, H., 2006, Critical Factors in the Adoption and Diffusion of eGovernment Initiatives in Oman, Doctor of Philosophy Thesis, School of Information Systems, Faculty of Business and Law, Victoria University. 